\title{
Biotechnological

\section{Biodegradation of cotton seed soapstocks by novel indigenous Bacillus species}

\author{
Gayatriben B. Patel and Kamlesh R. Shah \\ Department of Biotechnology,Pramukh Swami Science and H.D. Patel Arts College, Kadi, India
}

\begin{abstract}
Soapstocks is a value-added by-product separated from vegetable oil refining operations. Bacillus $s p$. is a good enzyme producer. The present research paper focused at isolation, screening and identification of Bacillus sp. from soapstock samples. Cotton seed soapstock samples used in the study were 7\% oil rich gelatinous dark brown chemical compound, which were enriched, serially diluted and spread on tributyrin agar plates, to isolate lipase positive cultures. Qualitative analysis of lipase producing microorganisms was done by plate assay on tributyrin agar plate and zone of hydrolysis measured. Bacillus $s p$. were further screened for cellulase and protease production by plate assay. Two cultures were identified on the basis of molecular and biochemical characteristics as Bacillus licheniformis (3B) and Bacillus pumilus (18B). Among selected Bacillus cultures Bacillus licheniformis and Bacillus pumilus gavegood zone of lipase and cellulasehydrolysis. Bacillus pumilus was highly protease producing organism. Quantitative analysis of Lipase production activity measured spectrophotometrically using p-nitrophenyl palmitate (p-NPP) as substrate. Bacillus licheniformis showed $1.72 \mathrm{U} / \mathrm{ml}$ lipase productions whereas Bacillus pumilus (18B) has $2.59 \mathrm{U} / \mathrm{ml}$. Phylogenetic trees showed similarity with other highly similar species.
\end{abstract}

KEY WORDS: BACILLUS LICHENIFORMIS, BACILLUS PUMILUS, LIPASE, P-NPP, PHYLOGENETIC TREES

\section{INTRODUCTION}

Industrial wastes, vegetable oil processing factories, soil contaminated with oil etc contain oily environment which provides a good environments for lipase producing microorganisms (Vandana et al., 2014). Soapstocks is a gelatinous dark brown undesirable chemical compound product from vegetable oil refining operations (King et al., 1998). Crude oil contamination in the environment has lots of hazard and so remediation of crude oil creates area of interest for research (Guru et al., 2013). Microbes secrete various enzymes among them lipase which helps

\section{ARTICLE INFORMATION:}

*Corresponding Author: hisonu2408@yahoo.co.in Received 12 $2^{\text {th }}$ July, 2018

Accepted after revision $18^{\text {th }}$ Sep, 2018

BBRC Print ISSN: 0974-6455

Online ISSN: 2321-4007 CODEN: USA BBRCBA

\%.: Thomson Reuters ISI ESC / Clarivate Analytics USA and

: Crossref Indexed Journal

NAAS Journal Score 2018: 4.31 SJIF 2017: 4.196

$\odot$ A Society of Science and Nature Publication, Bhopal India 2018. All rights reserved.

Online Contents Available at: http//www.bbrc.in/

DOI: $10.21786 / \mathrm{bbrc} / 11.3 / 21$ 
in degradation of oil (Veerabagu et al., 2014). Research in bacterial lipases is of great demand now because of value added potential industrial application (Sirisha et al., 2010). Industries are seeking lipase producing strains of bacteria which contain excellent properties using cost effective methods on large scale production (Bharathi et al., 2018).

Lipase (triacyl glycerol acylhydrolases, EC 3.1.1.3) catalyzes the hydrolysis of triacyl glycerol to glycerol and long chain fatty acids at oil water interface (Pualsa et al., 2013). Research can be done toward lipases from plant and animal origin but lipases from microbial origin are receiving much attention with the rapid development of enzyme technology. Lipase act as biocatalysts constitute the significant important role for biotechnological applications (Hasan et al., 2006, Saxena et al., 1999). Microbial lipases constitute much application such as in the detergent industry, food industry, paper and pulp industry, organic synthesis, bioconversion in aqueous media, resolution of racemic acids and alcohols, regioselectiveacylations, ester synthesis, oleochemical industry and lipases in medical application (Sharma et al., 2001, Verma et al., 2012, Mauti et al., 2016, Saraswat et al., 2017)

This study was conducted to isolate lipase producing bacteria which were screened on tributyrin agar plates. They were further analyzed for cellulase and protease production by plate assay. The bacterial genus Bacillus were identified on the basis of biochemical tests and molecular 16s r DNA Partial Gene sequencing analyzes. Quantitative analysis of lipase production was done spectrophotometrically using p-NPP as substrate. Further study will conducted on enzymatic degradation.

\section{MATERIAL AND METHODS}

Soapstock samples were collected from two different cotton oil refinery industries nearby Kadi (North Gujarat), India. At the starting season of cotton (November), Soapstock samples were collected from the flowing stock at Washer discharge end of the pipe in a sterile and air tight container. B/H (Bushnell-Haas) medium was selected for enrichment of cotton seed oil soapstocks for microbial growth (Guru et al., 2013).10 gram of cotton seed oil soapstock samples were added to 100 $\mathrm{ml}$ of $\mathrm{B} / \mathrm{H}$ mediums and incubated at $37^{\circ} \mathrm{C}$ in static condition for 5 days. From each sample, $1 \mathrm{ml}$ of enriched samples were transferred to the $100 \mathrm{ml}$ of Tributyrin broth medium incubated at $37^{\circ} \mathrm{C}$, in shaking condition at 100rpm for 48 hours. Enrichment was performed over a 7 days of incubation.Enriched Soapstock samples were serially diluted Diluted samples were spread on to Tributyrin agar medium for isolation of Bacteria .TBA Plates were incubated at $37^{\circ} \mathrm{C}$ for 2 days. Isolated colonies were purified on same medium by streak plate method. Pure cultures isolate were preserved at low temperature in Nutrient agar slants for screening and further use. Lipase-producing strains were screened by qualitative plate assay according to Lokre et al., 2014. Isolates were spot inoculated on tributyrin agar plates and incubated at $37^{\circ} \mathrm{C}$ for 2 days. Zone of clearance was observed due to hydrolysis of tributyrin by lipase enzyme.

Cellulase and Protease activity were done by qualitative agar plate assay in nutrient agar media containing respective substrates. Culture was spot inoculated and incubated at $37{ }^{\circ} \mathrm{C}$ for 2 days. Check for the zone of clearance around the colonies due to utilization of the particular substrate.

Culture was grown in medium containing 1\% carboxy methyl cellulose (Dabhi et al., 2014). After incubation the CMC plates were flooded with $0.1 \%$ congo red staining, after $5 \mathrm{~min}$ stain was discarded and the plates were distained by $1 \mathrm{M} \mathrm{NaCl}$ solution with continuous stirring for 15-20 min. The clear zone around colonies indicated cellulose hydrolysis.Protease activity was checked in medium containing 1\% skim milk as substrate (Prabavathi et al., 2012). Spot inoculated cultures were incubated at $37^{\circ} \mathrm{C}$ for 2 days and observed for clearance zone around colonies.

Selected Bacterial cultures that show Positive lipase production in plate assay, which were subjected further for Quantitative estimation. 2 days old bacterial cultures grown on TBA medium were used for inoculation. One loopfull culture was inoculated into $100 \mathrm{ml}$ of inoculum medium containing: peptone 0.5\%, Yeast extract $0.5 \%, \mathrm{NaCl} 0.5 \%$ and cotton seed 0il 1\%. Cultures were incubated at $37^{\circ} \mathrm{C}$ and $100 \mathrm{rpm}$ for $4 \mathrm{hrs} .5 \%$ inoculum medium was further inoculated into $100 \mathrm{ml}$ of same medium (as mentioned above) for lipase production and incubated at $37^{\circ} \mathrm{C}$ and $100 \mathrm{rpm}$ for 5 days. Enzyme assay was performed according to the method by Winkler et al., 1997 with some modification. The culture filtrate (production medium) was removed at $24 \mathrm{hr}$ interval from each flask \&t centrifuged at 10,000 rpm for $10 \mathrm{~min}$ at $4^{\circ} \mathrm{C}$. Supernatant was used for enzyme assay. Lipase activity was determined by a spectrophotometric assay using p-nitrophenyl palmitate (pNPP) as substrate. P-NPP was hydrolysed by lipase to give $\mathrm{p}-\mathrm{NP}$ which gave yellow color, absorbance of which was measured spectrophotometrically at $410 \mathrm{~nm}$ against enzyme free blank. Statistical Analysis were done in Microsoft word excel data analysis of lipase production.

The isolates showing maximum zone of clearance were selected for further analysis. Morphological and biochemical characteristics of the isolates were studied for the identification of the potent Bacterial isolate. Molecular characterization of potent Bacterial strains 
was done by $16 \mathrm{~s}$ rDNA partial Gene sequencing analysis. It was carried out at Biogene department of GSBTM, Gandhinagar.

The bacterial isolates were identified on the basis of their morphological characteristics (like cell shape, Gram staining, spore staining and motility) and biochemical tests viz. According to Cappuccino et al.,1996 biochemical test were done like Voges Proskaurtes test, Citrate utilization, Gelatin hydrolysis, Nitrate reduction, Ornithine decarboxylase, Lysine decarboxylase, Catalase test and hydrolysis, Indole test, Starch hydrolysis, H2S production, and Gas production from glucose. The utilization of different sugars was studied using bacterial identification kit from HiMedia.

\section{MOLECULAR IDENTIFICATION USING 16S RDNA SEQUENCING}

Two bacterial isolates (3B and $18 \mathrm{~B}$ ) were identified using $16 \mathrm{~S}$ rDNA sequencing. DNA was isolated from these bacterial isolates and its quality was evaluated on 1.2\% agarose gel. The 16S rDNA gene was amplified by PCR from the above isolated DNA and the PCR amplicon was purified to remove contaminants. 16S rDNA gene was generated from forward and reverse sequence data using aligner software. The 16S rDNA gene sequence was used to carry out BLAST with the nr database of NCBI gene bank database. Based on maximum identity score first ten sequences were selected and aligned using multiple alignment software program Clustal W. Distance matrix was generated using RDP database and the phylogenetic tree was constructed using MEGA 4.

\section{RESULTS AND DISCUSSION}

\section{SCREENING AND ISOLATION OF LIPOLYTIC BACTERIA}

From enriched Soapstock samples, total 49 pure cultures were isolated. Among them 30 cultures were bacterial isolates. All 30 bacterial isolates were lipase positive, 6 bacterial cultures were protease producers and 10 bacterial cultures were cellulase producers. Best two highly positive cultures were selected on the basis of qualitative analysis of lipase, cellulase and protease by plate assay as shown in Table 1 and Fig 1. In 2014 Ali et al, reported that the lipolytic bacterial Spp. isolated from oil contaminated soil were dominantly from genus Bacillus and Psudomonas with 23\% percentage of occurrence of Bacillus spp. among different bacteria in samples, fol-

\begin{tabular}{|l|l|l|l|l|}
\hline \multicolumn{5}{|l|}{ Table.1 Measures of Clear zone diameter to colony diameter ratio of bacterial isolates. } \\
\hline Sr. no & Bacterial Isolate & Clear Zone Diameter & Colony Diameter & Ratio \\
\hline \multicolumn{7}{|c|}{ Lipase activity } \\
\hline 1 & Bacillus licheniformis (3B) & $20 \mathrm{~mm}$ & $15 \mathrm{~mm}$ & $1.33 \mathrm{~mm}$ \\
\hline 2 & Bacillus pumilus (18B) & $22 \mathrm{~mm}$ & $16 \mathrm{~mm}$ & $1.37 \mathrm{~mm}$ \\
\hline \multicolumn{7}{|c|}{ Cellulase activity } \\
\hline 1 & Bacillus licheniformis (3B) & $9 \mathrm{~mm}$ & $5 \mathrm{~mm}$ & $1.80 \mathrm{~mm}$ \\
\hline 2 & Bacillus pumilus (18B) & $9 \mathrm{~mm}$ & $5 \mathrm{~mm}$ & $1.80 \mathrm{~mm}$ \\
\hline \multicolumn{7}{|l|}{ Protease activity } \\
\hline 1 & Bacillus licheniformis (3B) & $30 \mathrm{~mm}$ & $16 \mathrm{~mm}$ & $1.87 \mathrm{~mm}$ \\
\hline 2 & Bacillus pumilus (18B) & $31 \mathrm{~mm}$ & $10 \mathrm{~mm}$ & $3.10 \mathrm{~mm}$ \\
\hline
\end{tabular}
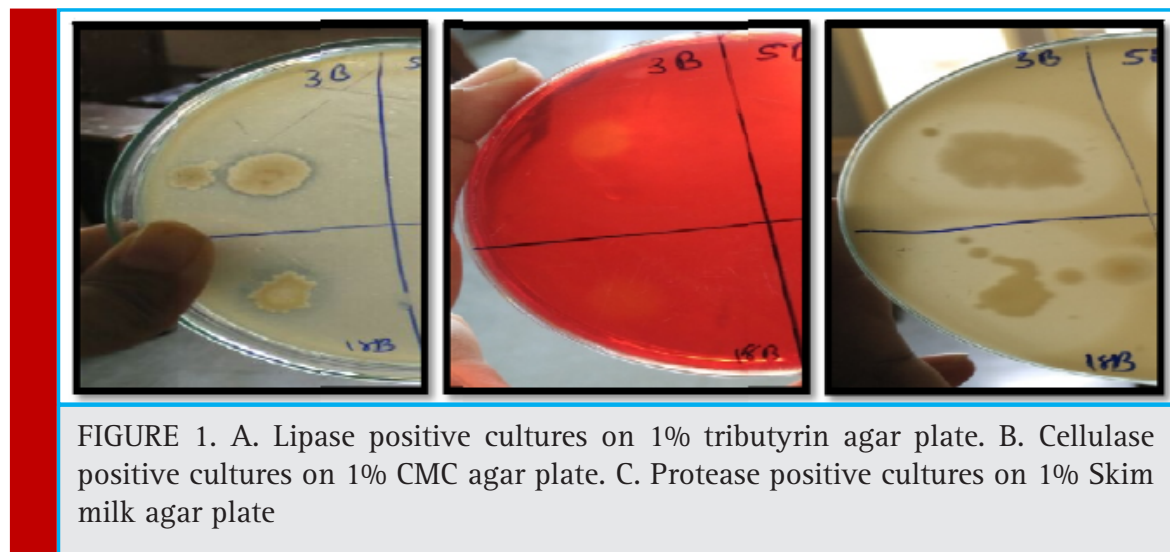

FIGURE 1. A. Lipase positive cultures on $1 \%$ tributyrin agar plate. B. Cellulase positive cultures on 1\% CMC agar plate. C. Protease positive cultures on 1\% Skim milk agar plate 

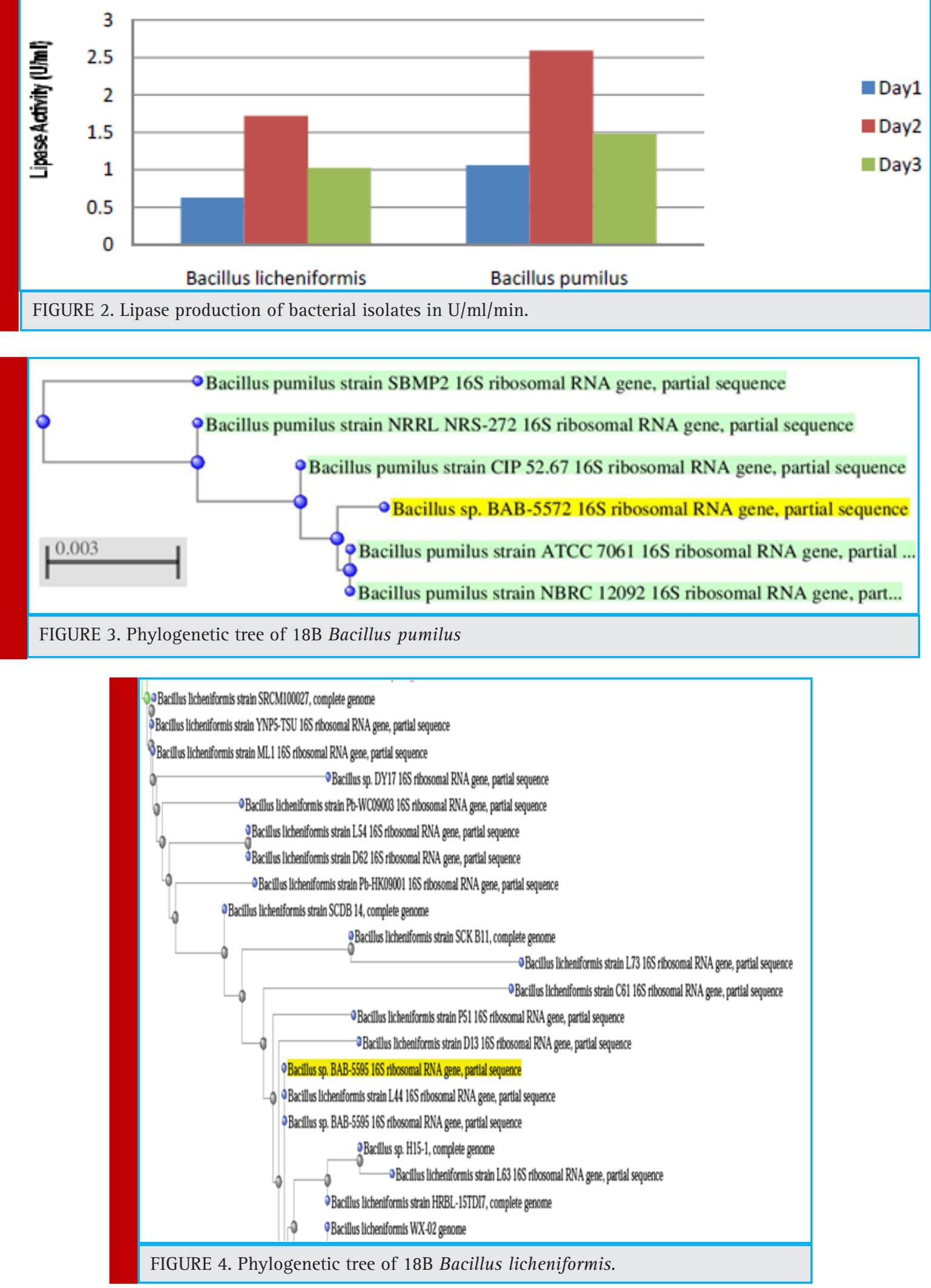
Gayatriben B. Patel and Kamlesh R. Shah

\begin{tabular}{|c|c|c|c|}
\hline Sr. no & Biochemical test & Bacillus licheniformis (3В) & Bacillus pumilus (18B) \\
\hline 1 & Gram's staining & Gram positive & Gram positive \\
\hline 2 & Motility & + & + \\
\hline 3 & Endospore & - & - \\
\hline 4 & Methyl red & + & + \\
\hline 5 & VogesProskauer's & + & + \\
\hline 6 & Citrate Utiliation & + & + \\
\hline 7 & Indole & + & + \\
\hline 8 & Glucuronidase & + & + \\
\hline 9 & Nitrate reduction & + & + \\
\hline 10 & PYR & + & + \\
\hline 11 & ONPG & + & + \\
\hline 12 & Lysine utilization & + & + \\
\hline 13 & Esculin hydrolysis & + & + \\
\hline 14 & Arginine utilization & + & + \\
\hline 15 & Lactose & - & - \\
\hline 16 & Xylose & - & - \\
\hline 17 & Maltose & + & - \\
\hline 18 & Fructose & + & + \\
\hline 19 & Dextrose & + & + \\
\hline 20 & Galactose & + & + \\
\hline 21 & Raffinose & - & - \\
\hline 22 & Trehalose & + & + \\
\hline 23 & Melibiose & - & - \\
\hline 24 & Sucrose & + & + \\
\hline 25 & L-Arabinose & + & + \\
\hline 26 & Mannose & + & + \\
\hline 27 & Inulin & + & $+1-$ \\
\hline 28 & Sodium gluconate & + & + \\
\hline 29 & Glycerol & + & + \\
\hline 30 & Salicin & + & + \\
\hline 31 & Dulcitol & + & + \\
\hline 32 & Inositol & + & + \\
\hline 33 & Sorbitol & + & $+1-$ \\
\hline 34 & Mannitol & + & + \\
\hline 35 & Adonitol & - & + \\
\hline 36 & Arabitol & - & + \\
\hline 37 & Erythritol & + & + \\
\hline 38 & alpha-Methyl-D-glucoside & + & + \\
\hline 39 & Rhamnose & + & - \\
\hline 40 & Cellobiose & + & + \\
\hline 41 & Melezitose & - & + \\
\hline 42 & alpha-Methyl-D-Mannoside & + & - \\
\hline 43 & Xylitol & - & + \\
\hline 44 & ONPG & - & + \\
\hline 45 & Esculin & - & + \\
\hline 46 & D-Arabinose & + & + \\
\hline 47 & Citrate utiliation & - & + \\
\hline 48 & Malonate & - & - \\
\hline 49 & Sorbose & + & + \\
\hline
\end{tabular}


lowed by Pseudomonas spp. 18\%. Bacillus sp. has been potential for production of proteases and lipases (Sangeetha et al., 2010). Bacterial Bacillus species are the prominent source of lipases in which $B$. subtilis (Shah et al., 2006), Bacillus pumilus (Sangeetha et al., 2008), Bacillus licheniformis (Madan et al., 2009, Sangeetha et al., 2010) are potent strains for lipase enzyme production. For the enzyme production we have done plate assay with various enzymes like lipase, cellulase, protease from which B.pumulis gives maximum zone of hydrolysis of 1.37 $\mathrm{mm}$ with lipase and $3.10 \mathrm{~mm}$ with protease while Bacillus licheniformis and Bacillus pumulis gives same maximum zone of hydrolysis of $1.80 \mathrm{~mm}$ with cellulase. From the above isolated organisms, Bacillus pumilus, Bacillus licheniformis isolates were found to be true lipase, protease and cellulase producers giving maximum zone of hydrolysis. Further screening was done for various enzymes. The isolate $3 \mathrm{~B}$ and $18 \mathrm{~B}$ which further quantitatively tested for production of crude lipase by pNPP as assay substrate and are efficient to produce $1.72 \mathrm{U} /$ $\mathrm{ml}$ and $2.59 \mathrm{U} / \mathrm{ml}$ of crude lipase enzyme respectively depicted in figure 2.

In Statistical Analysis p- value analyzes for control, $3 \mathrm{~B}$ and 18B lipase productions were $<0.0016,<0.024$ and $<0.020$ respectively. Bacillus pumilus is the best possible isolate having highest lipase production and was further screened and optimized for lipase production. The maximum amount of lipase production was obtained on the day 2 nd with recoverable enzyme activity gradually decreasing thereafter in shaking conditions. Consequently, further studies were carried out on cultures incubated for 3 days to obtain enzyme production. Biomass production remained stable, after which the culture reached the stationary phase. This forces microbes to produce enzymes to degrade crude oil to utilize it as a source of energy and these enzymes which were capable of producing certain secondary metabolites (Guru et al., 2013, Adnan et al., 2018) P. gessardi was a novel lipase degrading bacteria from the oil spilled soil which can be useful for the remediation of oil contaminated soil. (Veerabagu et al., 2014), Pseudomonas synxantha PS1 a lipase producing strain from oil well produced water having strong biodegradabitility of waste grease (Cai et al., 2016) as well as fungi aspergillus nigar able to degrade petroleum hydrocarbon (Mauti et al., 2016)

It can be concluded that from the results of the present study that Bacillus pumilus could be used as new potent microbial source of lipase. In further studies pilot scale production and purification studies will be conducted.

\section{CHARACTERIZATION OF BACTERIAL ISOLATES}

The bacterial isolates which showed maximum zone of clearance for lipase production were subjected to further characterization and identification by morphological, biochemical and molecular (by 16s rDNA sequencing) characteristics. The culture code 3B known as Bacillus licheniformis with accession Number KU728636 and 18B known as known as Bacillus pumilus with accession Number KU728634. Phylogenetic trees are show in Fig. 3 and 4.

From the table- 2 we conclude from microscopic, morphological, cultural characteristics and biochemical studies that the organism is gram positive rod, aerobic, mesophilic, highly mobile, non-endospore former, lactose non fermenting Bacillussp..Based on its morphological and physiological characteristics, the isolates were given for $16 \mathrm{~s} r$ RNA and it was confirmed that they belong to Bacillus genus.

\section{CONCLUSION}

Screening for lipase producing cultures from cotton oil refinery industries and resulted in the isolation of 49 isolates including bacteria $\&$ fungi.The isolate which showed highest production of lipase in plate assays were further quantitatively tested for production of lipase by pNPP as substrate assay. The culture was identified by morphological and molecular basis as Bacillus licheniformis \& Bacillus pumilus. Culture was deposited in the NCBI culture collection center with accession number. Presence of cellulase and protease enzyme may help in degradation study.

\section{ACKNOWLEDGMENTS}

The authors wish to express their thanks to the Department of Biotechnology, Pramukh Swami Science and H.D. Patel Arts College, Kadi. Gujarat State Biotechnology Mission at Gandhinagar for the valuable advices in the identification of the Bacterial Spp.

\section{REFERENCES}

Adnan B. Al- Hawash, Maytham A. Dragh, Shue Li, Ahmad Alhujaily, Hayder A., Xiaoyu Zhang and Fuying Ma (2018): Principles of microbial degradation of petroleum hydrocarbons in the environments. Egyptian journal of Aquatic Research.; 44:71-76.

Ali L., Nangyal H., Wali A., Gul-e- Sahra, Ahmad T. (2014): Screening of oil contaminated soil for isolation of lipids degrading bacteria. Sci. Int. (Lahore); 26: 1595-1600.

Bharathi, D., G. Rajalakshmi, S. Komathi (2018): Optimization and production of lipase enzyme from bacterial strains isolated from potrol spilled soil. Journal of king saud university Science; $1-4$

Cai Xianghai, Siqi Chen, Hong Yang, Wel Wang, Lin Lin. Yaling Shen, Wei Wei and Dong-ZhiWei (2016): Biodegradation of waste grease and biochemical properties of a novel lipase from 
Pseudomonas synxantha PS1, Canadian journal of Microbiology, 62: 588- 599.

Cappuccino, JGS N.J.G. Cappuccino, N. Sherman (1996): Microbiology: A laboratory Manual (No. QR63. C36 1996).

Dabhi, BK Vyas R.V. and Shelat H.N. (2014): Use of Banana Waste for the Production of Cellulolytic Enzymes under Solid Substrate Fermentation Using Bacterial Consortium. Int. J. Curr.Microbiol. App. Sci.; 3:337-346.

Guru G. S, Gohel H. R, Panchal M. R, Ghosh S. K and Braganza V. B (2013): Isolation and Enrichment of Microbes for Degradation of Crude Oil. International Journal of Engineering Science and Innovative Technology (IJESIT); 2:144-147.

Hanan S. A. (2012): Isolation and screening of extracellular proteases produced by new Isolated Bacillus sp. Journal of Applied Pharmaceutical Science; 2:071-074.

Hasan F., Shah A. A., and Hameed A. (2006): Industrial applications of microbial lipases. Enzyme Microb Techno; 39(2):235251

King J. W., Taylor S., Snyder J. M., and Holliday R. (1998): Total Fatty Acid Analysis of Vegetable Oil Soapstocks by Supercritical Fluid Extraction/Reaction. JA0CS; 75:1291-1295.

Lokre S.S. and Kadam D.G. (2014): Screening of thermostable lipase producers from alkaline lake. Int. J. Curr. Microbiol. App. Sci.; 3:240-245.

Madan, B., P. Mishra (2009): Over expression, purification and characterization of organic solvent stable lipase from Bacillus licheniformis RSP-09. Journal of molecular microbiology and biotechnology; 17(3):118-123.

Mauti, GO., J. Onguso, D. K. Kowanga and E. M. Mauti (2016) Biodegradation activity of Aspergillus niger Lipase isolates from a tropical country Garage. Journal of Scientific and Innovative Research; 5(1):15-18,

Patagundi B. I., Shivasharan C. T. and Kaliwal B. B. (2014): Isolation and Characterization of Cellulase producing bacteria from Soil. Int. J. Curr. Microbiol. App. Sci; 3:59-69.

Prabavathi R., Mathivanan V. and Ambika A. (2012): Screening of protease enzyme By construction of Metagenomic library from Marine soil sediments. International Journal of Pharma Sciences and Research; 3:396-399.

Pualsa J., Verma D., Gavankar R., and Bhagat R. D. (2013): Production of microbial lipases isolated from Curd using waste oil as a substrate. Research Journal of Pharmaceutical, Biological and Chemical Sciences; 4:831- 839.

Sangeetha R., Geetha A., Arulpandi I. (2008): Optimization of protease and lipase production by Bacillus pumilus SG 2 isolated from an industrial effluents. The Internet Journal of Microbiology; 5:61-65.

Sangeetha R., Geetha A., Arulpandi I. (2010): Concomitant production of protease and lipase by Bacillus licheniformis vsg1: Production, purification and characterization. Brazilian journal of microbiology; 41:179-185.

Saraswat, R V. Verma, S. Sistla and I. Bhushan (2017): Evaluation of alkali and thermotolerant lipase from an indigenous isolated Bacillus strain for detergent formulation. electronic journal of biotechnology; 30:33-38.

Saxena R. K., Ghosh P. K., Gupta R., Davidson W. S., Bradoo S. and Gulato R. (1999): Microbial lipases : Potential biocatalyst for the future industry. Current Science; 77: 101-115.

Shah K. R., Patel P. M., Bhatt S. A. (2007): Lipase production by bacillus sp. Under different Physio-chemical conditions.Journal of Cell and Tissue Research; 7:913-916.

Sharma R., Chisti Y. , Banerjee U. C. (2001): Production, purification, characterization, and applications of lipases. Biotechnology Advances; 19:627 - 662.

Sirisha E., Rajasekar N. and Narasu M. L. (2010): Isolation and Optimization of Lipase Producing Bacteria from Oil Contaminated Soils. Advances in Biological Research; 4:249-252.

Vandana P., Peter J. K. (2014): Comparative Study for Lipase Production by Using Pseudomonas aeruginosa and Pseudomonas fluorescens. International journal of engineering sciences \&t research technology; 3:31-34.

Veerapagu M., Sankara N. A., Jeya K.R., Alagendran S. (2014): Isolation and Identification of a Novel Lipase Producing Bacteria from Oil Spilled Soil. International Journal of Innovative Research in Science, Engineering and Technology; 3:18122 $-18129$

Verma N., Thakur S. and Bhatt A. K. (2012) Microbial Lipases: Industrial Applications and Properties. International Research Journal of Biological Sciences; 1:88-92.

Winkler U. K., Stuckman M. (1997): Glycogen, hyluronate and some other polysaccharides greatly enhance the formation of exo-lipase by Serrati amarescens. J. Bacteriol; 138:663-670. 